Manolis Kalaitzake*

\title{
Accounting for success: The Big Four as allies of finance in post crisis regulatory reform
}

\begin{abstract}
This paper argues that the Big Four accountancy firmsPricewaterhouseCoopers, Deloitte, Ernst \& Young, KPMG-operate as key political allies of the financial sector within financial regulatory battles. Leveraging the theoretical notion of "actor plurality" within the policymaking process, I demonstrate how, in the case of the European Union Financial Transaction Tax (FTT) initiative, accountancy professionals offered crucial support for the financial sector. They did so by disseminating key oppositional claims against the FTT proposal, developing tax mitigation and relocation strategies, preparing negative impact assessments, and advising on lobbying tactics. This allied stance of the Big Four is primarily a consequence of the ways in which their commercial priorities have been fundamentally transformed by the provision of consultancy services within the modern global economy. Moreover, the paper shows how accountancy experts are deeply embedded within a network of professional relationships that fosters substantive policy alignment between the Big Four and prominent financial lobbying groups. By highlighting the overlooked role of the major accountancy firms within post crisis regulatory reform, the study illuminates the unequal power relations that permeate financialized societies and contributes to a deeper understanding of how financial preferences continue to prevail within the policymaking process.
\end{abstract}

Keywords: financial political power, Big Four accountancy firms, financial regulation, European Union, Financial Transaction Tax

doi:10.1017/bap.2019.6

The author wishes to acknowledge helpful comments on previous drafts of this paper by Gary Robinson, Marco Andreu, Ciarán O' Flynn, and Christopher May. He would also like to thank the organisers and attendees of the 2018 Warwick Critical Finance Group Writeshop for which this paper was initially produced.

*Corresponding author: Manolis Kalaitzake, Postdoctoral Researcher, Max Planck Institute for the Study of Societies, Cologne, Germany; Email: kal@mpifg.de

(C) V.K. Aggarwal 2019 and published under exclusive license to Cambridge University Press. This is an Open Access article, distributed under the terms of the Creative Commons Attribution licence (http://creativecommons. org/licenses/by/4.0/), which permits unrestricted re-use, distribution, and reproduction in any medium, provided the original work is properly cited. 


\section{Introduction}

In the decade following the 2007/08 financial crash, there has been an abundance of work geared towards analyzing the continued politico-economic salience of the financial sector, and in particular, financial actors' ability to emerge more or less victorious within the policymaking process. ${ }^{1}$ In no area has this theme been more prevalent than financial sector regulatory reform. Despite the promise of a major overhaul by elected officials, and the seemingly conducive political environment to in-depth reforms, there is unanimity among scholars that changes to financial regulatory regimes have been cosmetic rather than systemic, and status quo orientated rather than paradigm shifting. ${ }^{2}$ This is not to say that that important measures have not been pursued and implemented at the transnational/national level, ${ }^{3}$ but rather that the substance and scope of these changes are remarkably conservative when placed in the context of such a severe crisis, popular resentment, and deep-seated deficiencies in the architecture of financial governance. ${ }^{4}$ The relative leniency accorded to the financial sector is perhaps best illustrated by the European Union, where a variety of reform proposals have been watered down, postponed, and in some cases, completely abandoned. ${ }^{5}$

Explanations abound for the ability of finance to escape thoroughgoing regulatory reform. For some, the prevalence of state rivalries fosters disagreement over policy priorities as countries seek to protect their nationally-specific financial systems from competitive disadvantage. ${ }^{6}$ Similarly, others point to the hegemonic resistance of the United States to accept a radical overhaul of the sector, encouraging other regions to follow suit with tepid reform measures. ${ }^{7}$ Other authors stress the post crisis resilience of economic ideas that cohere with the maintenance of a liberal regulatory paradigm, with some technocratic tinkering at the edges. ${ }^{8}$

Another line of explanation, and the one that this paper intends to build upon, emphasizes the multiplicity of ways through which the financial sector is able to exert political influence over the policymaking process and beat back (or substantially dilute) regulatory measures directly at odds with their perceived interests. As such, a particularly vibrant and ever-expanding sub-category of financial political

\footnotetext{
1 Moran and Payne (2014); Davis and Williams (2017).

2 Mügge (2013; 2014a); Helleiner (2014).

3 Mackintosh (2014).

4 Young and Yagci (2018).

5 Bieling (2014); Mügge (2014b).

6 Howarth and Quaglia (2013).

7 Young and Yagci (2018), 2.

8 Schmidt and Thatcher (2013).
} 
power explanations highlight the disproportionate lobbying/organizational resources deployed by financial actors, ${ }^{9}$ their capacity to remain embedded in key decision-making networks, ${ }^{10}$ and the ineluctable structural constraints that liberalized financial markets impose on ambitious regulatory endeavors. ${ }^{11}$

Within this explanatory framework, scholars have recently advanced the argument that the involvement of non-financial sector allies within the policymaking process can be a decisive factor in buttressing financial political power and helps to explain why the sector has retained its political prominence in the post crisis era. ${ }^{12}$ For instance, Pagliari and Young show how derivative regulatory initiatives in both the United States and Europe were significantly watered down due to the mobilization of non-financial, corporate end-users who saw the legislation as damaging to their own interests. ${ }^{13}$ As such, the authors claim that if financial actors garner the support of non-financial sector allies to their cause, they will be able to "leverage" their interests within the policymaking process and stand a better chance of attaining their preferences. Support for this proposition has been demonstrated elsewhere with reference to the allied support of finance by non-financial corporations (NFCs), ${ }^{14}$ central bankers, ${ }^{15}$ regulators, ${ }^{16}$ and the media. ${ }^{17}$

This paper seeks to extend these arguments and contribute to the scholarship of financial political power by analyzing the role of several extremely important financial regulatory participants that have, thus far, been entirely overlooked by the literature. That is, the role of the "Big Four" accountancy firmsPricewaterhouseCoopers (PwC), Ernst and Young (EY), Deloitte, and KPMGwho operate as ubiquitous participants in a range of policymaking debates, offering their professional services to both the official sector and the private sector. The Big Four firms are especially prominent players within the EU policymaking process, ${ }^{18}$ primarily as a consequence of their management consulting expertise across a range of (financial) policy areas including tax, information technology (including FinTech), capital market development, fraud detection, asset management, and regulatory compliance. As consistent actors within the domain of financial regulation, there is a pressing need to interrogate the political agency and

9 Sennholz-Weinhardt (2014); Orban (2016).

10 Tsingou (2015); Underhill (2015).

11 Bell and Hindmoor (2015); Bieling (2014); Woll (2016).

12 Pagliari and Young (2014; 2015).

13 Ibid. (2014).

14 Young and Pagliari (2017); Kastner (2018).

15 Kalaitzake (2018); Braun (2018).

16 Stellinga and Mügge (2017).

17 Happer (2017).

18 Financial Times, 9 July 2018, "Big Four paid millions to advise Brussels on tax policy." 
motivations of such entities with respect to major policy battles. This paper argues that these non-financial firms are, despite their pretence to neutrality, key supporters of the financial industry, and operate as important allies in aiding financial firms to oppose and resist regulatory reform. In this manner, they have the potential to play a contributory role in helping finance maintain its politico-economic prominence in the post crisis era.

Specifically, this paper argues that the allied support of the Big Four accountancy firms is rooted in the tight commercial links and professional interactions that habitually occur between the accountancy/professional service sector and the financial industry. As financial services firms are the largest clients of the Big Four, accountancy professionals have a strong interest in promulgating the political concerns of financial actors and acting on their behalf in relation to potentially threatening regulatory proposals. Moreover, due to the fact that they are deeply enmeshed within private financial sector networks and maintain close links with financial lobbying associations, Big Four professionals generally uphold a critical perspective on far-reaching regulatory reforms.

A key theoretical idea developed throughout is that the rallying of key support groups behind finance is not necessarily a contingent and highly variable occurrence premised upon, for instance, the content of a policy measure, its presumed impact on economic performance, or the specificities of the process through which the initiative travels. Rather, the backing of financial sector preferences by nonfinancial groups might be a more systematic-and hence durable-phenomenon that arises from the commercial dependence of groups (such as the accountancy profession) on a thriving and expanding financial industry. Consequently, the empirical investigation suggests that allies like the Big Four do not need to be actively recruited or persuaded to join in the policy fight against measures targeting the financial sector; instead, a sympathetic policy stance derives from the competitive desire of these firms to adequately service both the administrative and political needs of their most lucrative clients within finance. In this regard, the embedding of financialization within advanced economies is seen to fundamentally restructure the core incentives and material interests of certain social groups and, in turn, their political outlook on financial policymaking.

In order to unpack the political agency of the Big Four, I interrogate their role in relation to the EU Financial Transaction Tax (FTT) initiative-one of the more radical regulatory proposals that directly threatened the interests of the financial sector in the post crisis era. Although the eventual defeat of the FTT proposal has been investigated by several authors, ${ }^{19}$ there has been no analysis of the activities of the Big Four throughout this hard-fought policy battle. As such, it is an

19 Kalaitzake (2017); Kastner (2018); Gabor (2016). 
appropriate "typical" case to examine the Big Four's multifaceted assistance to the financial industry in opposing the charge and offers further empirical evidence of the unique capacity of the financial sector to prevail in regulatory policymaking.

The first section briefly elaborates on the relevance of actor plurality for the political power of finance in regulatory reform, relating this phenomenon to the political context of the EU FTT and problematizing the motivational basis of policy allies. The second section then traces the contours of a broad economic and political alignment of accountancy professionals with the continuing expansion of the financial sector, arguing that this tight convergence of interests is the result of a structural shift in Big Four business priorities from auditing to management consultancy services. The third and largest section examines the empirical implications of this alliance in the case of the EU FTT, focused specifically on identifying the policy stance and political agency of the Big Four. Drawing upon documentary material published by the Big Four and the European Union, the paper shows how the major accountancy firms unambiguously supported the financial sector by disseminating key oppositional claims against the proposal, constructing tax mitigation/relocation strategies, preparing negative impact assessments, and advising on lobbying tactics. The final section concludes and indicates some directions for future research.

\section{Actor plurality and financial political power}

Although there is a wide literature pinpointing different reasons for failed regulatory ambitions in the post crisis era, there is no a priori purpose for these explanations to remain analytically detached from one another. As is widely acknowledged, real world events typically involve a complex combination of causal mechanisms that interact to produce highly specific empirical outcomes. ${ }^{20}$ As such, many of the explanations advanced to account for frustrated financial reform work perfectly well together in providing a more holistic understanding of policymaking outcomes. For instance, the ideas-centred notion that a "resilient liberalism" remains institutionally entrenched within financial governance coheres substantially with a "regulatory capture" claim of purposeful financial representatives wielding disproportionate influence through informational advantages and their longstanding involvement in elite policy networks. ${ }^{21}$ Similarly, the reluctance of politicians and regulators to follow through on reform measures that may hurt their own, nationally-configured, financial system is not only a

20 Hedström and Ylikoski (2010).

21 For example, Underhill (2015). 
product of state rivalries, but also reflects legitimate economic caution in a globalized environment of ubiquitous capital flight and increasing financialization. ${ }^{22}$

One particular way, then, for more holistic explanations to be developed is through an analytic combination of institutional-based explanations along with power-based explanations. Indeed, some of the best work on contemporary business/finance-government relations go a long way towards integrating these explanatory strands. ${ }^{23}$ In terms of financial regulation, Pagliari and Young pursue a similar path by specifying "actor plurality" as a particularly crucial institutional condition that impinges upon the relative strength of business power. As referenced previously, greater involvement by groups that are not specifically targeted by the regulation in question often helps to strengthen financial sector influence by amplifying the financial sector's voice and buttressing their claims regarding potentially negative and unintended economic consequences. These allied claims commonly reinforce the attempt by financial actors to exercise a form of discursively constructed structural power and exploit the rational growthorientated fears of policymakers. ${ }^{24}$

Importantly, the effects of actor plurality are not unidirectional and it is certainly not impossible for greater, non-financial sector participation to work against the interests of finance. ${ }^{25}$ This may be through the engagement of civil society groups, trade unions, or even competing elements of their own sector. As a general rule, however, this type of mobilization against finance is rare. According to an empirical assessment of 250 regulatory items across several countries between 1999-2013, the level and character of outside involvement is unambiguously favorable to the financial sector. ${ }^{26}$ When non-targeted financial groups from the industry participate, they overwhelmingly act to support the sub-sector at risk of being regulated. Similarly, when non-financial actors engage, they are usually interest groups from the broader business community that are highly solidaristic with finance. These findings indicate robust business unity in the area of financial regulation. Just as important as business unity, however, is the fact that reform-supporting civil society groups have been largely disengaged from the post crisis regulatory process. ${ }^{27}$

Pagliari and Young formalize the actor plurality thesis by outlining several key environmental conditions that determine the degree of interest group

22 For example, Bieling (2014).

23 Bell and Hindmoor (2015); Culpepper (2011).

24 See Kalaitzake (2017); Sennholz-Weinhardt (2014).

25 Pagliari and Young (2014), 600.

26 Ibid. (2015), 314-22.

27 Scholte (2013). 
participation in regulatory policy initiatives. First is salience, indicating the amount of public attention given to any particular regulatory topic. Second is complexity, suggesting that the more technically complicated a debate is, the less likely it is that outside groups will engage in the policy process. Third is the level of governance, stipulating that the more remote a policy site-e.g., within the cloistered domain of supranational institutions, as opposed to national parliaments-there is a decreasing likelihood that non-targeted groups will mobilize (due to organizational constraints). Fourth is the "stage" of the policy process: this variable implies that the regulated industry has a "first mover advantage" due to their early involvement with the regulatory process, operating to substantially shape the agenda before other actors become informed of reform consequences. ${ }^{28}$

Importantly, in at least three of these variables, the financial industry was on the political backfoot in the case of the FTT. The relative salience of a potential FTT was extremely high after the financial crisis and the use of public money for the bailout of financial institutions. Indeed, public attention (and anger) towards the financial sector was exacerbated throughout the 2010-15 period due to the Eurozone crisis, corresponding exactly with the timeframe of the FTT debate. Furthermore, the complexity of the FTT issue was particularly low. While the nuts and bolts may be complicated, the FTT is an extremely intuitive policy measure: it imposes a modest and uniform taxation charge on all financial sector transactions with the explicit intention of making the industry contribute to the cost incurred by the crisis. Such a proposal had enormous popular appeal in terms of fairness and social justice. Moreover, one needs little technical understanding to see how the charge could disincentivize financial speculation that produces no clear social value. Certainly, compared to other items, such as hedge fund regulation or capital market development, there is a world of difference in the level of technical expertise required to understand a transaction tax. Lastly, in the case of the FTT, the financial sectors' first mover advantage was significantly neutralized due to the fact that the European Commission consciously crafted its proposal in relative seclusion from financial sector representatives. ${ }^{29}$

Of course, as the FTT policy was pursued at the supranational level, the process had the potential to become dominated by financial sector input. However, given that a wide variety of NGOs and unions had been working on similar proposals at the national level for a long time, this drawback was partially overcome, as evidenced by the substantial civil society involvement in the consultation period. ${ }^{30}$ Similarly, the Commission was motivated to provide dogged

28 Pagliari and Young (2015), 313-14.

29 Kastner (2018), 9.

30 European Commission (2011). 
support for the measure as it overlapped with several of their objectives, including the further generation of tax revenue, harmonized financial integration, and, crucially, restoring public trust and legitimacy in the context of crisis.

As documented by previous research, ${ }^{31}$ the financial industry faced a broad coalition on the FTT issue involving leading EU member states, the European Commission, Parliament, civil society groups, and was backed by a majority of EU citizens. The financial sector responded with its own formidable alliance involving leading financial lobbying associations, finance-dependent member states, such as the United Kingdom, non-financial corporations, and a variety of senior central bankers. Nevertheless, one group that has escaped attention within the literature on the FTT - and the literature on actor plurality-is the Big Four. This is an important area of inquiry given how the emergence of capital markets has heralded a concomitant rise in the relevance of capital market intermediaries: that is to say, a distinctive cluster of actors that deliver centrifugal services to lubricate the institutional cogs of contemporary financial markets. These include elements of the financial industry proper-such as hedge funds and private equity firms-but also groups from the established professions, such as legal outlets and the major accountancy firms. ${ }^{32}$

Before analyzing the specific involvement of the Big Four within the FTT debate, however, one particular aspect of the actor plurality thesis deserves to be more sharply problematized. While Pagliari and Young do a good job of specifying the conditions that impact the degree of interest group-involvement, the authors say very little about the character of the relationship between non-financial sector groups and the financial sector. As such, the impression given is that group intervention within the financial regulatory process is largely a contingent affair; one that depends on variable institutional criteria, as well as the (indirect) impact of the policy in question on that particular group. What is overlooked is that, for particular groups, supportive alliances with the financial sector might be a consistent and non-random occurrence premised upon more deeply embedded incentives that go far beyond the peculiarities of isolated policy measures and/ or varying environmental conditions.

This proposition is made all the more likely by the growing prominence of financial motives within contemporary society and the tighter coupling of economic decision-making by social actors with the priorities of the financial sector. ${ }^{33}$ Indeed, if the fallout of the financial crisis has illustrated anything, it is

31 Kalaitzake (2017); Kastner (2018).

32 Folkman et al. (2007).

33 In a subsequent piece, Young and Pagliari document empirically that finance generates greater "business unity" within policymaking compared to other corporate sectors such as 
how re-ordered economic interdependencies between actors in the age of financialization shapes strategic action and interests. It is in this vein that the present paper proceeds, demonstrating not only that the allied support of finance by the Big Four exists, but also delving into the systematic and durable motivations that engender this political alignment. As such, I indicate how the backing of the Big Four is a largely predictable and organic outcome of evolving commercial entanglements, resulting primarily (though not exclusively) from a distinctive shift in the business model of the accountancy profession over recent decades.

\section{The Big Four in finance-led capitalism}

A salient theme of research on professionals relates to how certain sectors, such as medicine, engineering, law, and accountancy, have undergone substantial commercialization as a result of competitive pressures and liberalizing policies within a globalized economy. ${ }^{34}$ These developments have heavily impacted the organizational structure of professional firms and led to an adaptation of their commercial practises vis-à-vis a more market-orientated business environment. These changes are particularly apparent in the sphere of accountancy and are best illustrated by the shift in priority away from their traditional work of auditing and towards the far more lucrative work of consultancy and tax advice provision.

Organizationally, the largest accountancy firms have reformed into a worldwide network of independent affiliates that are of central, functional importance to the "state-industrial-financial milieu" that spearhead contemporary economic transformation. ${ }^{35}$ This has facilitated the delivery of vital services to multinationals seeking to expand outwards from their domestic markets and capitalize on global economies of scale. While professionals offer specific knowledge of accounting standards and company law in foreign countries, they also provide a range of consultancy services necessitated by their clients' global ambitions, including Merger and Acquisition deals, and Initial Public Offerings-areas of enormous profitability in recent decades. Similarly, as financial markets and shareholders increasingly subject companies to buyouts and hostile takeovers, the major accountancy firms are key players in managing the necessary liquidation and receivership processes.

These developments are intimately tied to the rise of financialized activity within the world economy, and in particular, the rapid expansion of capital

energy, agriculture, and pharmaceuticals-though why this might be the case is left as an open question for future inquiry (2017), 18.

34 Brock et al. (1999); Greenwood and Suddaby (2006).

35 Hanlon (2004), 196; also, Shore and Wright (2018). 
markets. As the financially-driven notion of shareholder value incentivizes firms to focus on core aspects of their business and subcontract peripheral competencies, accountancy firms help to arrange the delivery of essential tasks such as telemarketing, billing, training, remuneration assessment, IT upgrading and digitization, etc. ${ }^{36}$ Big Four professionals also assist firms in engaging financial markets-commonly referred as the financialization of NFCs-especially the handling of complex derivative hedging, debt refinancing, and securities trading. As experts in treasury funds consultancy, professional accountants are pivotal to the sophisticated management of liquidity risk, asset and currency exposures, and leveraging pools of available capital for share buybacks and other forms of capital market investment. Furthermore, the fragmentation of global accumulation units and the establishment of offshore financial centres has created opportunities for the Big Four to construct and market highly complex tax strategies that are designed to arbitrage geographically-rooted state authorities. ${ }^{37}$ In short, the major accountancy firms have become a "one-stop shop" for consultancy services and operate as crucial "responsive functionaries" to contemporary financial-led restructuring. ${ }^{38}$ It is important to recognize the proactive opportunism on the part of major accountancy firms in seizing these commercial openings. Their embedded auditing relationship with large firms, for instance, made them privy to firm secrets and organizational deficiencies, thus offering a head start in selling non-traditional services to those clients. Similarly, accountancy professionals used their long-standing relationships with national governments to actively promote the policies of privatization and deregulation of key economic sectors-a major boon to financial markets in particular. Utilizing a language of technical neutrality and a presumed position of disinterested objectivity, accountants seized on the 1970s stagflation crisis by advising governments that liberalizing reforms were a necessary way of correcting stretched budgets and attracting inward investment. Similar opportunities presented themselves in the early 1990s as Eastern Europe was opened up to major capitalist overhaul, as well as further openings in China and other parts of the Asian market. ${ }^{39}$ Besides their extensive involvement in these projects, accountancy firms also became ideological backers of the new managerialism in the public health sector, schools and universities, local government, policing and prison reform, and other functions of state responsibility. ${ }^{40}$

36 Aharoni (1999), 27.

37 Sikka (2015).

38 Folkman et al. (2007), 557.

39 Aharoni (1999), 25.

40 Corporate European Observatory (2018), 10. 
In terms of their revenue stream, the Big Four are now overwhelmingly reliant on these finance-led commercial offerings. Based upon the most recent annual reports in 2017, each of the Big Four firms derived the large majority of their revenue-approximately $\$ 87$ billion per year, or 65 percent of their total income-from consultancy and tax advice. Deloitte-the largest of the Big Four-generated more than three quarters (76 percent) of its annual revenue from non-audit related activities, while PwC, EY, and KPMG generated 58 percent, 63 percent, and 61 percent, respectively. ${ }^{41}$ Year-on-year growth in management consultancy far outstrips the growth found in auditing services. For instance, in the five-year period from 2009 to 2013, consultancy and tax advice services grew by 27 percent across all the Big Four firms, contributing over $\$ 14$ billion worth of revenue. By contrast, auditing services lagged far behind with just $\$ 3$ billion in growth. ${ }^{42}$ Underlining this seismic shift in business priorities, the Big Four are now the top four consultancy firms in the world with a combined total of 40 percent market share, beating out household name firms such as McKinsey and Company, Boston Consulting, and Accenture. ${ }^{43}$

Crucially, financial services firms are the Big Four's largest clients by a substantial margin. In 2017, for the two largest accountancy firms, PwC and Deloitte, the financial sector constituted 32 percent and 28 percent respectively of their total revenue ( $\$ 22.7$ billion in total) (table 1$)$. The sectors that came closest to this-consumer and industrial-were each responsible for only half of these revenues. Importantly, income generated by governments and the public sector constituted just $\$ 7.5$ billion, or approximately a third of the income generated by financial sector clients.

All of the above indicates the close commercial alignment-and the potentially "allied" political stance-of accountancy firms vis-à-vis the financial sector. As such, there has been a growing focus on problems that arise due to the everincreasing consultancy role of the Big Four, usually highlighting one of two themes. The first relates to the role of the Big Four in facilitating the aggressive tax planning of major corporations. As revealed in the successive scandals of the Luxembourg leaks in 2014, the Panama Papers in 2015, and the Paradise papers in 2017, these complex tax arrangements-filtered covertly through byzantine capital flows across multiple jurisdictions-have ignited a major political debate

41 Authors calculations based upon annual reports publicly available from the websites of the Big Four.

42 Harris (2014).

43 See consultancy market share analysis at: https://www.consultancy.uk/news/2149/10-largestmanagement-consulting-firms-of-the-globe. 
Table 1: Revenue by industry of top two accountancy firms 2017 (billions in USD and percentages)

\begin{tabular}{|c|c|c|c|c|c|c|c|}
\hline & Financial services & Gov. and public services & Health & Energy & Tech. and media & Consumer & Industrial \\
\hline PwC & $12(32 \%)$ & $2.4(6 \%)$ & $3(8 \%)$ & $3.5(9 \%)$ & 4.7 (13\%) & $5.9(16 \%)$ & $6(16 \%)$ \\
\hline Deloitte & $10.7(28 \%)$ & $5.1(13 \%)$ & 3.7 (10\%) & $2.7(7 \%)$ & $4.5(12 \%)$ & $6.1(16 \%)$ & $6.1(16 \%)^{44}$ \\
\hline
\end{tabular}

Source: Author's calculations from Big Four annual reports

44 Estimated equal split of $\$ 12.2$ billion in total combined revenue from consumer and industrial services. No specific breakdown of these categories was available for Deloitte. 
concerning the legal (and ethical) status of the Big Four's tax advice. ${ }^{45}$ The second concerns declining auditing standards as demonstrated in a range of high profile cases over the last ten years, including Tesco, Carillion, Satyam, MF Global, Toshiba, Petrobras, and Monsanto, among many others. Furthermore, some of the most egregious failures occurred in the run up to the 2007-08 financial crash as the Big Four provided a clean bill of health to every one of the major financial institutions heavily invested in sub-prime debt and opaque securities, and that were dangerously overleveraged. ${ }^{46}$ To a significant extent, the issue of declining auditing standards relates back to unresolved problems following the Enron scandal in 2001 (which took down one of the then "Big Five," Arthur Anderson) and the WorldCom scandal in 2002. While legislative changes were passed to mitigate "conflict of interest" auditing errors-most notably, the Sarbanes-Oxley Act in the United States-they did little to stem the growth of Big Four consultancy. In fact, as noted by Peterson, "mandatory rotation" rules (forcing firms to periodically change their auditors) have actually incentivised firms to aggressively expand their advisory/consulting services even more, due to the politically-enforced short-term nature of auditing contracts. As a consequence, auditing functions receive progressively less resource allocation and investment. ${ }^{47}$

In the aftermath of the recent financial crisis, the threat of greater state intervention has forced the Big Four to engage in a process of institutional "re-legitimization" in order to refute the notion that they have become unduly motivated by narrow commercial interests, rather than the broader public good. A prime example of this occurred in the United Kingdom where the Big Four firms were chastized by a House of Lords audit inquiry committee as having "failed in prior attempts to self-regulate to avoid being dominated by vested interests, such as putting revenue above public duty." 48 Indeed, it is the expected "watchdog" status and supposed pursuit of a higher civic purpose that traditionally underpins the privileged social position of accountancy professionals, including the granting of oligopolistic rights and relative autonomy from state interference. Given that public officials have the legislative capacity to constrain these advantages, the Big Four must always make sure to cultivate an image of independence-or of being "above the fray"-regardless of what their changing business model suggests. ${ }^{49}$

\footnotetext{
45 Brooks (2018).

46 Kells and Gow (2018).

47 Peterson (2015), 122-23.

48 As documented by Whittle, Carter, and Mueller $(2014,795)$ this was the essential finding of the Economic Affairs Select Committee report on Audit Market Concentration in the United Kingdom. 49 Whittle et al. (2014).
} 
While these tax and audit scandals have grabbed front-page headlines and generated considerable academic debate, there has been no analogous interrogation of the Big Four's ubiquitous involvement in financial regulatory policy. This is a significant oversight, given that they offer specialist knowledge on regulatory construction, compliance, and implementation to both the financial sector and public officials. As such, the Big Four simultaneously represent clients that are frequently at odds with one another over the ultimate design of any given regulatory initiative. Moreover, despite presenting themselves as neutral proponents of objective information, there has been no systematic evaluation of this claim, while the evidence concerning their involvement in corporate tax planning and auditing challenges that assertion.

In this context, the next section undertakes a process tracing analysis of the primary contributions of accountancy professionals throughout the FTT policy debate. ${ }^{50}$ The FTT can be considered a "typical case" through which it will be useful to examine the role of the Big Four. ${ }^{51}$ This is because it involves a conventional subject matter-taxation and compliance-that relates directly to the functional commercial role of the major accountancy firms. The empirical setting thus facilitates an exploration and clarification of the causal mechanisms through which these firms assist the financial industry, as well as an appraisal of the kinds of argument they bring to bear on the policy debate.

\section{Case study of the EU FTT}

\section{Advancing the proposal}

Originally touted at the global level in 2009, the FTT was strongly backed by prominent EU leaders-Gordon Brown, Nicolas Sarkozy, and Peer Steinbrück-as a means to recoup large revenue from the financial sector towards the cost of the crisis, while also disincentivizing speculative activity within financial markets. Although dismissed by the United States and others at the G-20, the European Union made the surprise decision to push ahead with the plan, and in 2010, tasked the Commission with developing a proposal that would apply to all (then) twenty-seven member states. After considerable preparatory work, public consultations, and drafting of a directive, the proposal was again shot down at a series of Economic and Financial Affairs Council (ECOFIN) meetings, with

50 Process tracing analysis is recognized as one of the most appropriate methods for investigating the activities of private actors in policymaking. See Woll (2007), 74.

51 Seawright and Gerring (2008). 
strong opposition coming from the United Kingdom, Luxemburg, and several other heavily financial-dependent economies. While most observers expected this rejection to be the end of the proposal, significant support for the FTT still existed on the part of several leading member states, the Commission, the European Parliament, as well as there being overwhelming backing from civil society and the general population. As such, the Commission recommended that supportive member states go forward under the terms of "enhanced cooperation." Led by the Eurozone's four largest economies-Germany, France, Italy, and Spain-eleven countries (EU11) agreed to this plan, and the Commission busied itself with a second directive.

The resulting proposal by the Commission was a noticeably daring piece of legislation. Similar to conventional FTT measures, it advocated for a tax of a 0.1 percent on stocks and bonds transactions and a charge of 0.01 percent on derivatives, with the expectation that this would garner $€ 34$ billion annually in revenue for the EU11. However, given that the EU11 were planning to move ahead unilaterally, the Commission incorporated several unique design characteristics that aggressively combatted the potential for tax evasion and relocation by the financial sector-a chief concern of all FTT proposals. First, the Commission adopted a broad "AAA-approach" meaning the charge would apply to "all markets, all actors, and all instruments." Barring a small number of exemptions, this feature made it extremely difficult for financial actors to avoid the tax through adaptive trading strategies. Second-and most importantly-the Commission incorporated the "residence" and "issuance" principles. These legal criteria would close off loopholes relating to the relocation of firms, by coercively applying the charge to any transactions made with (very broadly defined) "established" EU11 entities and with instruments originating within EU11 states. In effect, in order for market participants-including those outside the European Union - to avoid the charge, they would have to completely forego all commercial interaction with the entire EU11 economic area; a highly unlikely strategy given that this jurisdiction constitutes two thirds of EU economic activity. ${ }^{52}$

The proposal was met with considerable outrage by the entire financial services sector who, between approximately 2010 to 2015, launched a continuous lobbying campaign against the measure. This campaign was conducted primarily by several transnational financial associations who eventually succeeded in defeating the measure through 1) securing a wide range of exemptions that undermined the core objectives of the tax (i.e., to garner substantial revenue and prevent avoidance/relocation), and 2) instigating political gridlock among participating countries at the Council of the European Union. As documented by several

52 European Commission (2013), 47. 
investigations, a key cause of victory for the financial sector was crucial policy interventions made by non-financial corporations and central bankers on behalf of the industry. ${ }^{53}$ However, the rest of this section addresses the overlooked role of the Big Four who also emerged as extremely active and valuable allies of finance.

\section{The Big Four as independent participants}

An important political consequence of the global financial crash is that financial actors have often tended to face a "more formal and more restricted" environment in dealing with policymakers/regulators, and have seen the credibility of their policy claims decrease. ${ }^{54}$ This certainly appears to have been the case in relation to the Commission as it emerged as a vocal advocate for the FTT and developed its proposal in "complete isolation" from the financial industry. ${ }^{55}$ As such, financial lobbyists reported finding it more difficult than ever to gain constructive policy interaction with policy officials, a marked change from the Commission's precrisis approach of relying on private financial sector impact studies to develop integration proposals. ${ }^{56}$ Similarly, in 2013, the Internal Market Commissioner Michel Barnier sent instructions to his staff to not meet with any representatives from the financial sector while working on several high-profile regulatory proposals. ${ }^{57}$

By contrast, the Commission largely retained an image of the Big Four as independent and essential confidantes within the policymaking process. For instance, PwC were heavily involved in the technical preparatory work for the FTT and were contracted by the Commission to carry out a study, which reviewed tax provisions on the financial sector across all EU member states and compared the difference in taxation rates applied the other economic actors. ${ }^{58}$ The Big Four were also participants in the Brussels Tax Forum in late 2011, created by the Commission to explicitly discuss potential options for further taxation of the financial industry. More generally, tax-related consulting contracts from the Commission have continued to be a huge source of revenue for accountancy firms in the post crisis era. For instance, the Big Four received approximately $€ 7$ million in revenue in 2014 and $€ 8$ million in 2016, to carry out various assessments and policy reports for the Directorate-General for Taxation and Customs Union. ${ }^{59}$

53 See Kalaitzake (2017); Gabor (2016); Kastner (2018).

54 Young (2013), 463-64.

55 Kastner (2018), 9.

56 Ibid., 9-10.

57 The Telegraph 19 December 2013, "Brussels chief Michel Barnier bans banker meetings."

58 European Commission (2011).

59 Corporate European Observatory (2018), 10; Financial Times, 9 July 2018, "Big Four paid millions to advise Brussels on tax policy." 
As a result of their perceived neutrality and sustained political access, one of the key selling points made by accountancy firms to the financial services sector throughout the FTT policy battle, was their ability to act as a conduit for the sector to influence policymakers. In brochures targeting the financial industry, PwC offered their assistance to help "devise the message and strategy around the engagement with government" and made clear that their "team members... have relationships with local industry groups and tax authorities to provide an avenue for constructive engagement with governments." ${ }^{60}$ In a similar fashion, Deloitte gave a commitment to "lobbying the FTT working groups" that would be organized by the European Union to discuss the technical challenges of policy implementation. ${ }^{61}$

The open consultation process is a good illustration of how, at a very early stage of the process (February-April of 2011), the Big Four functioned to relay the key concerns of the industry. Several of the Big Four made direct submissions, the most thoroughgoing of which was by EY-written by the global head of Tax Policy, Chris Sanger-which rejected the proposal at every turn. In response to whether or not it is justifiable to tax the financial sector in order to assist with fiscal consolidation efforts, the firm argued that, despite taxpayer support, the banking sector was in the process of fully repaying bailout funds. Furthermore, they contended that the industry is already burdened with new capital and liquidity requirements, as well as other regulatory costs, thus, "removing the need for tax change." EY also rejected the contention that the financial sector was especially undertaxed relative to the rest of the economy. Moreover, in relation to the FTT specifically, the firm claimed that the measure could inflict serious damage on capital markets, resulting in "far higher funding costs or total inability to access the markets" and argued that a "substantial number of exemptions [are] required across most capital market instruments." Finally, the firm argued that the capacity for taxation measures to positively impact upon market behavior is "unproven" and that imposing a unilateral FTT "would be catastrophic for the EU economy," resulting in major capital flight to alternative jurisdictions. ${ }^{62}$

Prominent interest groups closely associated with the Big Four were also instrumental in transmitting FTT warnings via consultation responses, including bodies such as the Federation of European Accountants (FEE), the Association of Chartered Certified Accountants (ACCA), and the American Chambers of Commerce to the EU (AMCHAM EU). These are highly active advocacy organizations that maintain links with the Big Four through membership status and/or the

60 PwC (2013a), 26-7.

61 Deloitte (2015), 2.

62 EY (2011). 
involvement of current or former employees. As such, individuals from the Big Four play a chief role in formulating policy positions and deciding upon issues on which to mobilize. ${ }^{63}$ Importantly, they are also sites through which senior accountants are integrated into broader technical and commercial networks in order to interface with public policymaking. In relation to the proposed FTT, each of these organizations adopted a highly negative stance. The FEE consultation letter was written by the president of the organization, Philip Johnson, formerly a senior partner at Deloitte in the United Kingdom, and displayed Petra Weymüller as the reference contact, a former associate with $\mathrm{PwC}$ and manager at Deloitte in Germany. The letter is extremely sceptical of the proposal stating that it is likely to "lead to price increases for financial services...affecting the costs of financing" and that it has the potential to "place the EU at a competitive disadvantage." It also questions the appropriateness of taxing the financial sector specifically, indicating that such a measure is not in line with the principle of "equal treatment." 64 Both ACCA and AMCHAM EU also threw cold water on the FTT proposal. ACCA made the case that "the net result to the EU of unilateral action would be a significant loss of both economic activity and tax" and argued that it is average consumers-or "lower value and less sophisticated customers" - who are most likely to feel the negative impact of the charge. ${ }^{65}$ Finally, AMCHAM EU stated that the measure would make the financial system considerably more insecure, damage European competitiveness, and result in costs ultimately being passed on to the consumer. ${ }^{66}$

It is difficult to adjudicate whether these negative assessments reflected sincerely held beliefs or a desire to protect a sector that accountancy firms depend upon for business. Indeed, it is quite likely that it was some combination of the two. Nevertheless, when taken together, the negative FTT claims contained a fundamental inconsistency that was shared in common with arguments deployed by financial sector associations. As noted incisively by financial expert and rare industry advocate for reform, Avinash Persaud, "We are told that the tax will be so completely avoided that no one will pay it. Then we are told that the tax will bring economic and financial ruin. It is hard to have it both ways." 67 At a minimum, then, this basic contradiction indicates a lack of nuanced assessment by Big Four analysts-an attribute widely promoted by those firms as their stock-in-trade-and betrays a willingness to put their commercial concerns above a strictly independent evaluation. Similarly, the Big Four made curiously

63 See Corporate European Observatory (2018), 12-4.

64 FEE (2011).

65 ACCA (2011).

66 AMCHAM EU (2011).

67 Financial Times. 28 May 2013, "Europe should embrace a financial transaction tax." 
little effort to engage arguments regarding the effectiveness of the robust antiavoidance measures that the Commission planned to put in place; measures that would render the policy quite unlike any previously attempted unilateral FTT. Instead, professionals invariably assumed that financial actors would-in conjunction with their commercial assistance (see below)-simply find new ways to circumvent the taxation measure. At a maximum, these arguments convey a strong predisposition to reflexively adopt the policy preferences of their major clients. Plainly capturing this tight alignment of viewpoints, the Commission summarized the consultation results by stating that "Registered financial organizations, non-registered financial organizations and the business, accounting/consulting and real estate subgroups generally oppose any and all types of additional tax burden on the financial sector or financial markets in general [italics added]." 68

\section{The dual service of the Big Four}

An interesting aspect of Big Four involvement in issues of financial regulation, such as the FTT, is that they stand to win regardless of the precise outcome. On the one hand, if the policy is passed, accountancy firms pick up business from the financial sector in relation to operations planning, including the implementation of compliance systems, and crucially, helping firms to develop mitigation strategies to minimize their exposure to the new charge. On the other hand, if the policy is defeated, the Big Four would also have reasons to cheer: in assisting with lobbying, they would be seen as instrumental in helping their clients beat back a highly unpopular measure, further establishing their reputation as a close and effective ally of the industry. Additionally, the more liberalized the financial services sector is, the more likely it is to grow, hence offering more business for professional service firms in the future. It is for these latter reasons that the Big Four were not content to sit on the sidelines and wait for business to accrue from passage of the FTT. The FTT was just one initiative out of a wide range of policy proposals pursued in the wake of the $2008 \mathrm{crash}$. Given their extensive commercial interaction with the financial industry, it made sense for the Big Four to help moderate a wholesale re-regulatory drive by public authorities that would severely restrict financial sector growth and potentially undermine consultancy opportunities over the long run. ${ }^{69}$ In this regard, the Big Four positioned themselves to

68 European Commission (2011).

69 Note that this argument does not necessarily imply deceitful intentions on the part of Big Four professionals; it should be recognized that the rational self-interest in consultancy opportunities may run in parallel with a sincere ideational view of the FTT as misguided policymaking. 
provide a dual service to the financial sector on the FTT issue: on one side of the equation, supplying operations advice on compliance and mitigation, and on the other, assisting them in strategic lobbying efforts.

On the operations side, accountancy firms were quick to advertize the various ways in which they would support the industry in preparing for the tax. As an illustrative example, EY set up a dedicated online FTT "knowledge centre" where financial services firms could get regular updates about policy developments, technical information on the proposals, impact assessments, and be put in touch with tax advisory experts to answer specific queries. The firm promoted a "multi-disciplinary approach" bringing together a team of "tax, operations, IT, finance and regulatory specialists" to work with different areas of their client's business. Leveraging upon their previous experience of working with firms to plan for the introduction of national-level transaction taxes, EY also offered technological supports for handling reporting and settling requirements, collection mechanisms, and budget allocations based upon tailored business assessments. ${ }^{70}$

The Big Four's assistance on these technical operations had crucial political implications. As mentioned, a critical component of advice centred on designing ways through which financial firms could minimize their exposure to transactions that would be liable for the new charge. Much like the euphemistic and neutral language used in relation to corporate tax planning, the Big Four highlighted their expert capacity to "mitigate" costs, "substitute" products, and help clients to "manage risk[s]" associated with the charge. Thus, KPMG promoted "identification of management and mitigation strategies," ${ }^{71}$ while Deloitte offered to "explor [e] ways to structure your products and transactions...to minimize the costs of [the] tax."72 Similarly, Deloitte offered their services to "identify securities, assets and transactions which have a lower FTT impact" for financial institutions, and to develop "alternative approaches to the structure of their groups treasury function" for non-financial firms that habitually engage with financial trading. ${ }^{73}$ Even more explicitly, a KPMG brochure outlines three specific techniques for minimizing costs. The first involves an assessment of the impact on profitability and decisions taken on whether the tax should be "absorbed, mitigated or passed on." The second involves an adjustment of a firm's business model, considering the possibility of "product substitution" and "relocation." The third step involves the

70 See EY FTT knowledge centre at: https://www.ey.com/gl/en/industries/financial-services/ banking-capital-markets/eu-ftt-knowledge-center.

71 See KPMG FTT FAQ at: https://home.kpmg.com/xx/en/home/services/tax/regional-taxcenters/eu-tax-centre/financial-transaction-tax/ftt-faq.html.

72 Deloitte (2015).

73 Ibid. (2013). 
management of risk, including "secondary liability" (i.e., knowing when costs will be passed on from another business client) and any "residual risks."74

To the extent that the financial industry-working in conjunction with Big Four advice-had the capacity to devise trading strategies that would circumvent and minimize the impact of the FTT, the less likely it would be that the policy would achieve its desired aims of bringing in large revenue and clamping down on speculative trading. In turn, the perception by governments that the policy would either fail or be rendered ineffective by these corporate maneuverings had the potential to tap into policymaker fears that a unilateral FTT would put their nation (and the EU11 region) at a significant competitive disadvantage. ${ }^{75}$ In this regard, the ostensibly disinterested technical assistance of the Big Four was heavily imbued with policy implications.

In terms of directly assisting the financial services sector with their political mobilization efforts, it is important to recognize the embedded position of the Big Four vis-à-vis the most active lobbying elements of the financial services industry. As demonstrated by studies of the FTT policy debate, it was this diverse collection of transnationally-orientated financial sector associations, rather than individual financial firms, that led the political charge against the initiative. Some of the most prominent of these associations include the Association for Financial Markets in Europe (AFME), the International Swaps and Derivatives Association (ISDA), and the European Fund and Asset Management Association (EFAMA) - all of whose members would be significantly impacted by an EUlevel FTT. Crucially, each of the Big Four firms hold an "associate" membership status with these organizations (with the sole absence of a formal AFME-KPMG partnership). This associate membership assures that the Big Four are kept abreast of the financial industry's main political concerns, while equally, the industry's senior lobbying associations can draw upon accountancy firms' professional expertise to buttress their policy claims. Likewise, the highly active European Banking Federation (EBF) was intimately connected to the Big Four due to the fact that the vast majority of their members-i.e., all of the leading nationallevel financial lobbying associations in the European Union-also reserved associate membership status for the major accountancy firms. Particularly telling is the fact that such affiliations are unique to the Big Four-financial sector relationship: in

74 KPMG (2017).

75 Kalaitzake (2017, 720-21) shows that the EU11 coalition ultimately fractured on the matter of whether or not a full-throated FTT design (as advocated by the Commission) or a watered down version should be pursued. As I discuss further below, the growing desire of governments to exempt particular trades from the FTT only increased the opportunity for Big Four firms to devise complex avoidance strategies. 
an assessment of six leading NFC business associations within the largest EU countries, none of these groups maintained an associate membership status for the Big Four. ${ }^{76}$

Besides these institutional interlinkages, many of the individuals working within these financial lobbying associations have career overlaps with the Big Four. For instance, the Director of Prudential Regulation at AFME, Mark Bearman, was previously a manager at KPMG's Risk and Regulatory Practise unit, advising on Basel II implementation. Similarly, AFME's Director of Technology and Operations, David Ostojitsch, worked as a Senior Manager for PwC on capital market Strategy and Technology transformations. From the other direction, the current Managing Director at PwC Canada, Jim Buckley, previously served on the ISDA steering committee. In short, there is an extremely tight-knit and functionally interconnected network of professional relationships that fosters substantive policy alignment between the Big Four and the main financial sector lobbying groups.

These relationships facilitated close political interaction on the question of the FTT and helped to advance a more cohesive and effective oppositional message to both policymakers and the public. As demonstrated, accountancy firms immediately adopted a policy stance that closely matched the financial sector outlook, and circulated this message through participation in the consultation process and in their public documents. However, a particularly sophisticated political strategy, advised by the Big Four, involved encouraging different elements of the industry to focus on watering down the tax and securing key exemptions related to their own commercial dealings, rather than full-scale rejection. Given that nationallevel FTT's were implemented unilaterally in France (in 2012) and Italy (in 2013), PwC judged that a watered-down approach would be a fruitful tactic in the case of an EU FTT: "the most effective and constructive engagement with government will be that which seeks to inform the policy intent with practical input/ experience (e.g. limit the instruments in scope, etc.) rather than arguing against an FTT in its entirety [italics added]." ${ }^{\prime 7}$ Highlighting the ambitious scope of the tax and its impact upon virtually all actors, PwC stressed how each segment of the industry could "legitimately be pressing for special treatment/exemptions"78 and indicated that delays to the political process create "good opportunities for lobbying to shape

76 This includes BDI (Germany), MEDEF (France), CONFINDUSTRIA (Italy), CEOE (Spain), VNO-NCW (Netherlands), and Swedish Enterprise (Sweden). Note that the Confederation of British Industry (UK) do not maintain a public list of full and associate members. For information on all EU countries, see https://www.businesseurope.eu/members.

77 PwC (2013a), 21.

78 Ibid. (2012), 3. 
the proposed FTT regimes over the coming months." ${ }^{79}$ Similarly, Deloitte made the case that financial actors should work to lobby for "exemptions or amendments focused on those FTT aspects which would hit your business hardest or the greatest uncertainties of the FTT directive." 80

As it turned out, the achievement of multiple exemptions was decisive in the ultimate failure of the policy, as it substantially increased the opportunities for tax evasion and jurisdictional relocation (precisely what the operational advice from the Big Four would seek to exploit), while also undermining the core objective of generating large revenues. Recognizing this threat, taxation Commissioner Algirdas Šemeta made a (failed) last-ditch plea to policymakers to avoid "hollowing out" the proposal, stating that "the worst-case scenario would be if members agree to a FTT but it is so full of holes that financial transactions shift abroad." 81 Nevertheless, this fraught debate on exemptions fostered divisions within the Council of the EU and resulted in a series of postponements, leading to political exhaustion among EU11 participants. While some policymakers became convinced of the need to include special exemptions to protect certain elements of the industry (e.g., pensions, secondary market bonds, repurchase agreements, etc.), others questioned the benefit of moving ahead with the measure at all if it was to be so heavily-diluted as to be counterproductive. ${ }^{82}$ As such, the FTT soon descended into political limbo, despite the occasional claim from EU officials that the policy would be resurrected at some point in the future. ${ }^{83}$

A final significant aspect of lobbying assistance came through the construction of a major FTT impact assessment "literature review" by PwC. Produced at a critical moment of the policy process-two months before the initially intended implementation date of January 2014-the report was commissioned by a who's who of all the major financial sector/private industry lobbying bodies across Europe. Besides a plethora of financial sector associations, it also included prominent employer associations from the United Kingdom (Confederation of British Industry) and France (The Mouvement des Entreprises de France), the latter of which played a critical role in turning the Hollande government against the proposal. ${ }^{84}$ Out of the total twenty-seven lobbying bodies that commissioned the PwC report, it also included the City of London-based International Regulatory Strategy

79 Ibid. (2013b), 1.

80 Deloitte (2013), 4.

81 Reuters, 18 January 2014, “'Don't Hollow Out Financial Transactions Tax,' Says EU Tax Chief"

82 Kalaitzake (2017), 720-21.

83 Reuters, 19 June 2018, "Germany's Scholz proposes Europe-wide unemployment insurance scheme."

84 Kalaitzake (2017), 720. 
Group (IRSG), which draws extensively upon leading Big Four figures to staff its chair, council, executive board, and expert groups.

Crucially, although the report was presented as a neutral "literature review" giving voice to both sides of the argument, its findings and conclusions are heavily skewed towards the perspectives and interests of the financial sector. Thus, in its impact section, the report brings together a range of arguments from Oliver Wyman, Oxera, London Economics, CBI, and the EFAMA, all of which make disastrous predictions regarding the unintended consequences of the measure for money markets, repo markets, bond markets, derivative markets, as well as overall GDP growth. ${ }^{85}$ More importantly, the PwC report reaches a range of its own conclusions that are definitively in line with its funders' opposition to the FTT. The report suggests that "there is limited empirical evidence to adequately support [the] assertion" that an EU FTT will reduce market volatility-a key Commission objective-and argues that its implementation "could in fact encourage risk taking rather than the opposite as intended." ${ }^{86}$ Furthermore, PwC rejects the suggestion that the financial sector is "undertaxed," arguing that "the sector bears a significant tax burden" that disproportionately contributes to the overall economy. Finally, PwC claim that the envisaged measure "creates scope for complex behavioral responses and relocation of financial activity to non-participating jurisdictions." 87 As indicated previously, such "complex behavioural responses" resulting in evasion and relocation would be largely the result of strategic tax planning advice delivered by the Big Four.

Given that the PwC report was commissioned by a large faction of leading FTT opponents, it is reasonable to expect that policymakers would receive these findings with caution. Yet, in the absence of any direct response from the official sector, it is not possible to say with any precision how much-if at all-these professional evaluations impacted subsequent decision-making. What is clear, however, is that the literature review functioned to reinforce the warnings of the financial sector and, at the very least, gave a more objective sheen to their core claims. It also had the benefit of consolidating the primary arguments against the FTT in one place, to be picked up by other business associations and the financial press. ${ }^{88}$ It is these rather subtle contributions that further speak to the political agency of the Big Four and resonates appropriately with their knowledge-based assistance to financial clients.

85 PwC (2013c), 8-9.

86 Ibid., 11.

87 Ibid.

88 Bloomberg, 25 November 2013, “Europe's Financial Transaction Tax Faces Challenges, PwC Says." 


\section{Conclusion}

This paper has provided theoretical elaboration and empirical analysis of the political role and motivations of the Big Four within the domain of post crisis financial regulation. Utilizing the notion of actor plurality, the paper shows how the policy involvement of accountancy professionals functioned to buttress financial actor claims and help the sector to oppose-but also prepare for and stay informed about-the ambitious FTT initiative. Above all, the study reveals that the purported neutrality of the Big Four on regulatory policy is a particularly unsustainable claim. This was evidenced by the independent engagement of the Big Four in the FTT consultation process, their multifaceted commercial offerings to financial firms (including lobbying advice), and their blanket insistence that an EU FTT was an ill-advised measure. Notably, the financial sector did not need to actively recruit the support of the Big Four; rather, political alignment on this issue emerged organically as a functional result of the close business relationship between finance and the accountancy sector. Moreover, the study showed that even purely technical advice is not necessarily apolitical or without important policy implications: the prospect of the Big Four designing bespoke trading strategies for FTT evasion bolstered the argument that capital would flee and render the EU11 area competitively disadvantaged.

A salient theoretical advancement relates to the motivational basis of the actor plurality thesis. In contrast to a distinctly contingent and highly variable perspective on actor plurality, this paper indicates a systematic and durable foundation to the Big Four-financial sector alliance. The central determinant of this alliance is the outsized commercial dependence of the Big Four in selling capital market-based consulting services-on average, 65 percent of their combined annual revenue. As such, there are strong prima facie reasons to expect the Big Four to side with financial sector preferences on financial regulation. As long as consultancy services remain an overwhelming source of revenue (and profit) growth, the Big Four have a clear vested interest in maintaining - indeed, strengthening-the prominence of a liberalized financial system. Similarly, with roughly one-third of Big Four revenue derived from financial clients, it is perfectly rational for these firms to stay closely attuned to the primary concerns of the industry, both economic and political. It is for this reason that the Big Four have established an unusually close relationship with leading financial lobbying associations. Of course, direct material interests are not all that matter: Big Four professionals are deeply embedded within networks that tend towards ideational complementarity with private sector perspectives and generally seek to preserve the conservative cast of 
regulatory policy, e.g., independent advocacy groups such as the FEE, ACCA, AMCHAM EU, and IRSG.

While these findings add significantly to our understanding of these key capital-market intermediaries, the study represents only a first foray into the Big Four-financial sector relationship and suggests promising avenues of future investigation. Most obviously, the concept of financialization offers a valuable analytical perspective to extend our knowledge of the striking commercial entanglement of the Big Four with finance. Several key processes of this phenomena-e.g., the involvement of NFC's in financial activities, the proliferation of shareholder value practises, the financialization of state operations ${ }^{89}$-are integral to both the business model of major accountancy firms as well as the dominant position of finance within contemporary economic life. As such, theorizing and empirically tracing the ways in which this unique convergence of practises and material interests translates into political co-operation (or not) is a central task for future research.

Similarly, the study has clear implications in terms of the drivers and barriers to post crisis regulatory reform and the renewed literature on financial political power. Important to point out here is that, while the preceding analysis specified the motivations, policy stance, and political agency of the Big Four, it made no claim regarding the precise impact of these various factors on the policy outcome. Although one can argue with confidence that several actions of the Big Four served to reinforce the claims of the financial sector, it is simply not possible to say whether the contributory role of the Big Four swayed the final decision of policymakers one way or the other. This is in part due to perennial methodological challenges intrinsic to the study of business power, and in part, a limitation of the particular case design. For instance, it is extremely difficult to disentangle the potential influence of the Big Four from that of other important oppositional actors, including NFCs, central bankers, and indeed, financial associations themselves. One way to overcome this challenge is to incorporate interviews with policymakers to help identify with more precision the key variables that influenced the final outcome. Furthermore, interviews would also provide general insight into the appraisal by policymakers of Big Four policy advice, as well as their interpretation of the close relationship between accountancy professionals and finance.

Besides this, the paper is also limited as a single case study. While appropriate for isolating the policy stance of the Big Four and detailing the varied mechanisms of support, it is not possible to generalize from a single case to other regulatory policies. What is required, then, is a comparative assessment of multiple regulatory

89 Fastenrath et al. (2017). 
initiatives involving the Big Four, which offer clear variation in outcomes, i.e., finance losses and victories. This would help to isolate the key determinants of policy influence, as well as provide a broader analysis of Big Four political operations. Furthermore, investigation into different regulatory issues would shed light on the motivations and activities of other capital market intermediaries-in particular, private law firms - who confront similar material incentives in the context of financialization and also possess superior technical expertise that the official sector relies upon to make informed policy choices. The prospect that professional entities akin to the Big Four provide consistent and systematic allied support for finance is a fertile area of academic inquiry and one that raises critical questions concerning the democratic functioning of economic governance in contemporary society.

\section{References}

Aharoni, Y. 1999. "Internationalization of professional services." In Restructuring the professional organization: Accounting, health care and law, edited by Brock, D., C. R. Hinings, and M. Powell, 20-40.

American Chambers of Commerce. 2011. "Response to European Commission Consultation on financial sector taxation.” Retrieved from: http://ec.europa.eu.

Association of Chartered Certified Accountants. 2011. "Response to European Commission Consultation on financial sector taxation." Retrieved from: http://ec.europa.eu.

Bell, S., and A. Hindmoor 2015. Masters of the Universe, Slaves of the Market. Cambridge, MA: Harvard University Press.

Bieling, H.J. 2014. "Shattered Expectations: The Defeat of European Ambitions of Global Financial Reform," Journal of European Public Policy 21 (3): 346-66.

Braun, B. 2018. "Central banking and the infrastructural power of finance: the case of ECB support for repo and securitization markets." Socio-Economic Review https://doi.org/10.1093/ser/ mwy008.

Brock, D. M., M. J. Powell, and C. R. Hinings (eds.). 1999. Restructuring the Professional Organization: Accounting, Health Care and Law. London: Routledge.

Brooks, R. 2018. Bean Counters: The Triumph of the Accountants and How They Broke Capitalism. London: Atlantic Books.

Corporate European Observatory. 2018. Accounting for influence how the Big Four are embedded in EU policy-making on tax avoidance. Brussels: Corporate European Observatory. Available at: https://corporateeurope.org/.

Culpepper, P. 2011. Quiet Politics and Business Power: Corporate Control in Europe and Japan. Cambridge: Cambridge University Press.

Davis, A., and K. Williams. 2017. "Introduction: Elites and power after financialization," Theory, Culture and Society 34 (5-6): 3-26.

Deloitte. 2013. “Financial transaction tax: Key Factsheet for Business.” Available at: https:// www2.deloitte.com/ie/en.html. 
Deloitte. 2015. "Financial Transaction Tax: It is moving forward.” Available at: https://www2. deloitte.com/ie/en.html.

Ernst and Young. 2011. "Response to European Commission Consultation paper on the taxation of the financial sector." Available at: http://ec.europa.eu.

European Commission. 2011. "Responses to Consultation on Financial Sector Taxation." Available from: http://ec.europa.eu/taxation_customs/common/consultations/tax/2011_02_financial_ sector_taxation_en.htm.

European Commission. 2013. "Impact Assessment: Implementing Enhanced Cooperation in the Area of Financial Transaction Tax." SWD/2013/28 final.

Fastenrath, F., M. Schwan, and C. Trampusc. 2017. "Where States and Markets Meet: The Financialization of Sovereign Debt Management," New Political Economy 22 (3): 273-93.

Federation of European Accountants. 2011. "Response to European Commission Consultation on financial sector taxation." Available at: http://ec.europa.eu.

Folkman, P., J. Froud, S. Johal, and K. Williams. 2007. "Working for themselves? Capital market intermediaries and present-day capitalism," Business History 49 (4): 552-72.

Gabor, D. 2016. “A Step Too Far? the European Financial Transaction Tax on Shadow Banking," Journal of European Public Policy 23 (6): 925-45.

Greenwood, R., and R. Suddaby. 2006. "Institutional entrepreneurship in mature fields: The big five accounting firms," Academy of Management Journal 49 (1): 27-48.

Hanlon, G. 2004. "Institutional forms and organizational structures: Homology, trust and reputational capital in professional service firms," Organization 11 (2): 186-210.

Happer, C. 2017. "Financialization, Media and Social Change," New Political Economy 22 (4): 437-49.

Harris, S. 2014. "The Rise of Advisory Services in Audit Firms." Speech at the Practicing Law Institute, 12th Annual Directors' Institute on Corporate Governance. 24 November. Available at: https://pcaobus.org/News/Speech/Pages/11242014_Harris.aspx.

Hedström, P., and P. Ylikoski. 2010. "Causal mechanisms in the social sciences," Annual review of sociology 36: 49-67.

Helleiner, E. 2014. The Status Quo Crisis. Oxford: Oxford University Press.

Howarth, D., and L. Quagli. 2013. "Banking on stability: the political economy of new capital requirements in the European Union," Journal of European Integration 35 (3): 333-46.

Kalaitzake, M. 2017. "Death by a Thousand Cuts? Financial Political Power and the Case of the European Financial Transaction Tax," New Political Economy 22 (6): 709-26.

Kalaitzake, M. 2018. "Central Banking and Financial Political Power: An investigation into the ECB," Competition and Change https://doi.org/10.1177/1024529418812690.

Kastner, L. 2018. "Business Lobbying under Salience-Financial Industry Mobilization against the European Financial Transaction Tax,” Journal of European Public Policy 25 (11): 1648-66.

Kells, S., and I. Gow. 2018. The Big Four: The Curious Past and Perilous Future of the Global Accounting Monopoly. Victoria, Australia: La Trobe University Press.

KPMG. 2017. "An overview of the proposed EU financial transaction tax." Available at: https:// home.kpmg.com.

Mackintosh, S. P. 2014. “Crises and Paradigm Shift.” The Political Quarterly 85 (4): 406-12.

Moran, M., and Payne, A. 2014. "Introduction: Neglecting, Rediscovering and Thinking Again about Power in Finance." Government and Opposition 49 (3): 331-41.

Mügge, D. 2013. "Resilient neo-liberalism in European financial regulation." In V. A. Schmidt and M. Thatcher (eds.), Resilient Liberalism in Europe's Political Economy. Cambridge: Cambridge University Press, 201-25. 
Mügge, D. 2014a. “Policy Inertia and the Persistence of Systemic Fragility.” Political Quarterly 85 (4): 413-16.

Mügge, D. (ed.). 2014b. Europe and the governance of global finance. Oxford: Oxford University Press.

Orban, A. 2016. "Mobilizing Moral Boundaries: The Politics of Derivatives Reform in the US." New Political Economy 21 (6): 555-73.

Pagliari, S., and K. Young. 2014. "Leveraged Interests: Financial Industry Power and The Role of Private Sector Coalitions.” Review of International Political Economy 21 (3): 575-610.

Pagliari, S., and K. Young. 2015. "The Interest Ecology of Financial Regulation: Interest Group Plurality in the Design of Financial Regulatory Policies." Socio-Economic Review 14 (2): 309-37.

Peterson, J. 2015. Count Down: The Past, Present and Uncertain Future of the Big Four Accounting Firms. Bingley: Emerald Publishing Limited.

PricewaterhouseCoopers. 2012. "The EU financial transactions tax: Unprecedented steps." FS viewpoint. July. Available at: http://www.pwc.com/.

PricewaterhouseCoopers. 2013a. "Financial Transaction Taxes: Developing a strategic response." FS viewpoint. February. Available at: http://www.pwc.com/.

PricewaterhouseCoopers. 2013b. "Latest developments on the EU Financial Transaction Tax deciphering the Brussels labyrinth.” FS viewpoint. January. Availabel at: http://www.pwc. $\mathrm{com} /$.

PricewaterhouseCoopers. 2013c. "Financial Transaction Tax: the impacts and arguments. A literature review." Available at: http://www.pwc.com/.

Schmidt, V. A., and M. Thatcher (eds.). 2013. Resilient liberalism in Europe's political economy. Cambridge: Cambridge University Press.

Scholte, J. A. 2013. "Civil Society and Financial Markets: What Is Not Happening and Why." Journal of Civil Society 9: 129-47.

Seawright, J., and J. Gerring. 2008. "Case selection techniques in case study research: A menu of qualitative and quantitative options.” Political research quarterly 61 (2): 294-308.

Sennholz-Weinhardt, B. 2014. "Regulatory Competition as a Social Fact: Constructing and Contesting the Threat of Hedge Fund Managers' Relocation from Britain." Review of International Political Economy 21 (6): 1240-74.

Shore, C., and S. Wright. 2018. "How the Big 4 got big: Audit culture and the metamorphosis of international accountancy firms." Critique of Anthropology. doi: 10.1177/0308275X18775815.

Sikka, P. 2015. “No accounting for tax avoidance.” The Political Quarterly 86 (3): 427-33.

Stellinga, B., and D. Mügge. 2017. "The regulator's conundrum. How market reflexivity limits fundamental financial reform." Review of International Political Economy 24 (3): 393-423.

Tsingou, E. 2015. "Club Governance and the Making of Global Financial Rules." Review of International Political Economy 22 (2): 225-56.

Underhill, G.R. 2015. "The Emerging Post-Crisis Financial Architecture: The Path-Dependency of Ideational Adverse Selection.” The British Journal of Politics and International Relations 17 (3): 461-93.

Whittle, A., C. Carter and F. Mueller. 2014. "Above the fray: Interests, discourse and legitimacy in the audit field." Critical Perspectives on Accounting 25 (8): 783-802.

Woll, C. 2016. "Politics in the interest of capital: A not-so-organized combat." Politics and Society 44 (3): 373-91.

Woll, C. 2007. "Leading the Dance? Power and Political Resources of Business Lobbyists." Journal of Public Policy 27 (1): 57-78. 
Young, K. 2013. "Financial industry groups' adaptation to the post-crisis regulatory environment: Changing approaches to the policy cycle." Regulation and Governance 7 (4): 460-80.

Young, K. L., and A. H. Yagci. 2018. "Status Quo Conservatism, Placation, or Partisan Division? Analysing Citizen Attitudes Towards Financial Reform in the United States." New Political Economy: 1-21.

Young, K., and S. Pagliari. 2017. "Capital united? Business unity in regulatory politics and the special place of finance.” Regulation and Governance 11 (1): 3-23. 